\title{
UPAYA MEREDAM MISKONSEPSI SISWA MELALUI MODEL DISCOVERY LEARNING PADA MATERI HUKUM II NEWTON DI SMPN 10 MALANG KELAS VIII
}

\author{
Wiwin Indriani Ina ${ }^{1}$, Kurriawan Budi Pranata ${ }^{2}$, Hena Dian $\mathrm{Ayu}^{3}$ \\ Pendidikan Fisika Universitas Kanjuruhan Malang ${ }^{1,2,3}$ \\ Email: wiwinindrianiina@gmail.com
}

\begin{abstract}
Abstrak. Penelitian ini dilakukan dengan maksud (1) mengetahui perbedaan miskonsepsi terhadap peserta didik yang memakai model pembelajaran DL dan model pembelajaran konvensional (2) mengetahui hubungan dari model pembelajaran DL dengan Three Tier Test terhadap miskonsepsi siswa. Teknik pengambilan sampel menggunakan Nonrandomised Control Group Posttest Design. Metode yang digunakan adalah eksperimen yang semu (quasi Experiment Design), dengan rancangan The Maching- only posttest control group design. Penilaian kemampuan awal siswa dilakukan dengan mengambil nilai rata-rata siswa sedangkan untuk penilaian miskonsepsi peserta didik dilakukan melalui posttest dan Three Tier Test. Data yang yang diperoleh kemudian diuji analisis dengan Uji Anova Dua Jalur (Two Way Anova) menggunakan bantuan program Microsoft Excel 2013. Berdasarkan data analisis data uji statistik diperoleh bahwa ada perbedaan miskonsepsi siswa yang belajar menggunakan model pembelajaran DL terhadap peserta didik yang belajar memakai model pembelajaran pada umumnya yaitu model pembelajaran konvensional. Hal tersebut di buktikan dengan analisis yaitu F_Hitung $>$ F_Tabel $(4.1>3.92)$, dengan taraf signifikansi 5\% dan diambil dari nilai rata-rata kemampuan awal siswa yang diajarkan dengan model pembelajaran DL lebih tinggi yaitu 80.033 dibandingkan dengan nilai pemahaman konsep siswa yang memakai model pembelajaran pada umumnya yaitu model pembelajaran konvensional dengan nilai yaitu 67,167. Sehingga dapat ditarik kesimpulan bahwa penelitian ini mengungkapkan dimana model pembelajaran DL membawa dampak positif.
\end{abstract}

Kata Kunci: Miskonsepsi, Hukum II Newton

\section{PENDAHULUAN}

Fisika adalah ilmu yang mempelajari tentang gejala atau fenomena alam. Sehingga untuk memahami fisika, tidak cukup dengan hanya memberikan teori, tetapi perlu dilakukan suatu penyelidikan. Hal ini sesuai dengan yang dikatakan Ayu, 2017 menyatakan "pembelajaran fisika seharusnya dapat memberikan pengalaman langsung kepada siswa sehingga menambah kemampuan dalam mengkonstruksi, memahami, dan menerapkan konsep yang telah dipelajari”. Dengan demikian, "siswa akan terlatih menemukan sendiri berbagai konsep secara holistik, bermakna, otentik serta aplikatif untuk kepentingan pemecahan masalah" (Ayu, 2017). Pernyataan tersebut juga selaras dengan pernyataan yang dikatakan oleh Hermansyah (2015) yang mengatakan "pembelajaran fisika menekankan pada pemberian pengalaman langsung untuk mengembangkan kompetensi siswa".

Pengetahuan mula-mula siswa yang dididapat dari pengetahuan siswa sering mengalami kesalahan konsep. Pemahaman awal membawa manfaat yang secara langsung maupun tidak langsung dalam proses pembelajaran, oleh sebab itu pengajar wajib memperhatikan materi sebaik mungkin sebelum pembelajaran dimulai agar terhindar dari miskonsepsi yang berdampak pada siswa itu sendiri. 
Tidak paham pada konsep yang berbentuk pengetahuan awal, kekeliruan yang tidak sesuai antara pengetahuan-pengetahuan, serta cara pikir yang salah. Novak \& Gowin (2014:9) menyatakan bahwa "miskonsepsi merupakan suatu interprestasi mengenai konsep-konsep dalam suatu pernyataan yang tidak bisa diterima. Miskonsepsi ialah pernyataan yang keliri dan suatu ide atau pikiran yang tidak sesuai dengan pengertian ilmiah yang diterima para ahli. Miskonsepsi secara rinci dapat merupakan pengertian yang tidak akurat terhadap konsep, penguasaan pengetahua awal yang salah".

Agar dapat mengetahui tidak paham konsep pada siswa peneliti menggunakan eksamen pengecekan. Depdiknas (2007) mengatakan bahwa "tes diagnostik adalah tes yang dipakai untuk mengungkapkan kelemahan-kelemahan siswa sehingga hasil tersebut dapat digunakan sebagai dasar untuk memberikan tindakan atau perlakuan yang tepat yang sesuai dengan kekurangan yang dimiliki peserta didik". Fariyani \& Wahyuningsih $(2013,2015)$ mengatakan "tes yang baik adalah tes yang dapat memberikan gambaran miskonsepsi yang dialami peserta didik secara akurat serta tes yang dapat mengungkap konsep-konsep yang belum dipahami dan telah dipahami”.

Three tier test adalah tes uji yang mempunyai beberapa tahap untuk memeriksa level miskonsepsi kepada peserta didik dengan harapan melalui tes tersebut peserta didik dapat meredam ataupun mengurangi miskonsepsi yang dialaminya. Dan tes ini adalah ekspansi (peningkatan) dari tes diagnostik yang terdiri dari 3 (tiga) tahap. Pertama adalah pernyataan opsi double dengan tiga opsi yang menjadi opsi yang mengecoh (mengelabui) dan opsi lainnya yang menjadi kunci jawaban dari pernyataan tersebut. Di tahap kedua, peneliti menyajikan 3 pernyataan yang belum pasti, opsi lain yang menjadi kunci jawaban dan opsi terakhir adalah alasan terbuka yang dapat masukkan sendiri oleh siswa menurut pendapat ataupun pengetahuan yang dimilikian. Tujuan pemberian argumen atau keterangan umum sebagai alternatif lain jika jawaban tidak terdapat pada opsi yang sudah disediakan serta menemukan adanya pendapat atau argumen yang berbeda dari siswa dalam memilih jawaban yang tidak tersedia pada keempat pilihan yang sudah ada. Dengan demikian, peneliti berharap miskonsepsi yang dialami siswa dapat diredam melalui penerapan model pembelajaran DL dengan memakai Three tier test.

Riset yang peneliti lakukan berbentuk eksperimen semu (quasi experimental), yang mana pada uji coba ini peneliti tidak memungkinkan untuk meninjau semua faktor beda yang dapat berefek pada keterlaksanaanya uji coba ini, sehingga faktor lain tersebut dinilai sama. Subjek dalam uji coba ini adalah siswa kelas 8 (delapan) SMP Negeri 10 Malang. Percobaan ini melibatkan 2 kelas, yaitu 8 (delapan) D menjadi jenis eksperimen dan 8 (delapan) E menjadi jenis kontrol yang mendapat tindakan yang berbeda. Kelas eksperimen diberikan tindakan menggunakan model pembelajaran Discovery Learning, sedangkan pada kelas kontrol menggunakan pembelajaran umum. Instrumen perlakuan dalam uji coba ini terdiri dari Silabus, Rencana Pelaksanaan Pembelajaran, dan (Lembar Kerja Siswa).

Adapun teknik penggabungan data, yaitu (1) eksamen (tes), (2) wawancara dan (3) foto. Eksamen dilakukan pada siswa dengan menggunakan soal tes tiga tingkat (three tier test). Data dianalisis melalui (a) Uji Normalitas yang diuji menggunakan uji liliofers berbantuan Microsoft Excel 2010, (b) Uji Homogenitas yang diuji dengan menggunakan uji Barlet dengan bantuan dengan bantuan MS. Excel 2010 (c) Uji Hipotesis yang diuji menggunakan uji analisis ANOVA (Analysis of Variance) memakai Aplikasi M. Excel 2007.

\section{HASIL DAN PEMBAHASAN}

Berdasarkan riset yang dilakukan terkait miskonsepsi Hukum II Newton, dapat dipaparkan pada tabel 1 (satu) dan 2 (dua), sebagai berikut: 
Tabel 1. Data Nilai Miskonsepsi Siswa berdasarkan

Model Pembelajaran DL

\begin{tabular}{llllll}
\hline Kelas & Model Pembelajaran & $\begin{array}{l}\text { Jumlah } \\
\text { Sampel }\end{array}$ & Nilai Miskonsepsi Siswa & Rata-rata \\
\hline & & & Tertinggi & Terendah & \\
\hline Eksperimen & Discovery Learning & 30 & 90 & 65 & 80.033 \\
\hline Kontrol & Konvensional & 30 & 80 & 50 & 67.167
\end{tabular}

Berdasarkan Tabel 1, berhasil dipahami bahwasanya kegiatan pembelajaran dengan memakai model pembelajaran DL mempunyai nilai miskonsepsi Hukum II Newton yang lebih rendah dengan nilai tertinggi 90 dan nilai terendah 65 sehingga mempunyai nilai rata-rata 80.033. Sedangkan kegiatan pembelajaran yang menggunakan model konvensional mempunyai nilai miskonsepsi Hukum II Newton dengan nilai tertinggi 80 dan nilai terendah 50 sehingga mempunyai nilai rata-rata 67.167. Tabel 1 menunjukan bahwa data miskonsepsi Hukum II Newton antara siswa grup eksperimen dan grup kontrol tidak sama.

Tabel 2. Data Nilai Miskonsepsi Siswa melalui Three Tier Test

\begin{tabular}{llllll}
\hline Kelas & Model Pembelajaran & $\begin{array}{l}\text { Jumlah } \\
\text { Sampel }\end{array}$ & Nilai Miskonsepsi Siswa & Rata-rata \\
\hline Eksperimen & Discovery Learning & 30 & 90 & Tertinggi & Terendah \\
\hline Kontrol & Konvensional & 30 & 79 & 60 & 76.3 \\
\hline
\end{tabular}

Berdasarkan Tabel 2, berhasil dipahami bahwasanya kegiatan pembelajaran yang menggunakan model DL mempunyai nilai miskonsepsi Hukum II Newton dengan nilai tertinggi 80 dan nilai terendah 60 sehingga mempunyai nilai rata-rata 79.9 Sedangkan kegiatan pembelajaran yang menggunakan model konvensional mempunyai nilai miskonsepsi Hukum II Newton dengan nilai tertinggi 79 dan nilai terendah 50 sehingga mempunyai nilai rata-rata 64.5. Tabel 2 menunjukan bahwa data nilai miskonsepsi Hukum II Newton antara siswa grup eksperimen dan grup kontrol tidak sama.

\section{Tabel 3. Hasil Uji Anova Dua Jalur}

\begin{tabular}{llcl}
\hline Source & Dependent Variable & df & Sig. \\
\hline Corrected Model & Miskonsepsi & 1 & .000 \\
\hline Intercept & Miskonsepsi & 1 & .01 \\
\hline Kelas & Miskonsepsi & 1 & .01 \\
\hline
\end{tabular}

Berdasarkan tabel 3, didapat nilai taraf relevan miskonsepsi siswa $0,000<0,05$. Hasil ini sesuai dengan spekulasi satu, yaitu ada perbedaan miskonsepsi siswa yang menggunakan Three Tier Test 0,01 $<0,05$. Model pembelajaran $D L$ dengan model pembelajaran Konvensional. Selanjutnya didapat nilai taraf relevan $0,01<0,05$. Hasil ini menunjukkan bahwa terjadi interaksi antara model pembelajaran $D L$ menggunakan Three Tier Test terhadap miskonsepsi siswa. Dari riset ini berhasil dipahami bahwasanya model pembelajaran DL dengan Three Tier Test dapat meredam miskonsepsi siswa dan juga ditemukan adanya perbedaan miskonsepsi siswa yang menggunakan model pembelajaran DL dan siswa yang belajar memakai model pembelajaran umum. Hal ini sesuai dengan penelitian Hosnan (2014) menunjukan bahwa penggunaan model 
pembelajaran DL dalam pembelajaran dapat meningkatkan kemampuan penemuan dan pemahaman konsep dibandingkan model pembelajaran konvensional.

\section{PENUTUP}

Dari hasil riset dan pemaparan diatas dapat disimpulkan bahwa (I) adanya perbandingan miskonsepsi pada siswa memakai model pembelajaran DL dan model pembelajaran konvensional, (II) adanya hubungan dari model pembelajaran DL dengan three tier test pada miskonsepsi siswa penggabungan data dan pemaparan dapat diambil kesimpulan bahwa: Ada perbedaan miskonsepsi siswa yang memakai model pembelajaran DL dengan siswa yang memakai model pembelajaran konvensional dan ditemukan adanya hubungan (interaksi) model pembelajaran DL melalui Three Tier Test terhadap miskonsepsi siswa.

Mengarah pada pembahasan dan hasil uji coba yang diperoleh, sasaran untuk penelaah ataupun penyelidik berikutnya agar model pembelajaran DL senantiasa diperluas dan dikembangkan lagi dilapangan dan dijadikan sebagai alternatif pilihan guru dalam kegiatan belajar mengajar dengan kolaborasi pengetahuan dan juga ide ataupun gagasan yang melatarbelakangi penelaah selanjutnya. Hal ini dikarenakan model pembelajaran ini dapat merangsang keaktifan peserta didik untuk mencari solusi yang diberikan dan membangkitkan semangat dan antusias belajar sehingga siswa mencapai tujuan pembelajaran yang baik dan optimal.

\section{DAFTAR PUSTAKA}

Ayu, H.D \& Jufriadi, A. 2017. Pengaruh Penerapan Strategi Open Ended Problem Bersetting Kooperatif Terhadap Kemampuan Menyelesaikan Masalah Ditinjau Dari Kreativitas Siswa. Jurnal Erudio, 7 (1): 1-6.

Arikunto, Suharsimi. 2013. Dasar-dasar Evaluasi Pendidikan. Jakarta: Bumi Aksara

Depdikbud. (2015). Buku Guru Ilmu Pengetahuan Alam. Jakarta: Pembukuan Balitbang.

Depdiknas. (2006). Kurikulum Tingkat Satuan Pendidikan. Jakarta: Pembukuan Balitbang.

Derosari, M. 2010. Pengaruh Pembelajaran Konteskstual Berbasis Hands On Problem Solving terhadap Kemampuan Pemecahan Masalah Siswa pada Materi Pesawat Sederhana denganRancangan Penelitian Pretest dan Posttest Design di SMP Kartika IV-9 Malang. Skripsi tidak diterbitkan: FST Unikama

Fahturrohman, Muhammad. 2015. Model-model Pembelajaran Inovatif. Jogjakarta: Ar-Ruzz Media

Hamdani. (2011). Strategi Belajar Mengajar. Bandung: PT Bumi Aksara http://www.ekaikshanudin.net (Pembelajaran Model Discovery Learning) Kelebihan dan Kekurangan Model Discovery Learning (http://www.infosekolah87.com )

Moedjiono, Dimyati. 1993. Strategi Belajar Mengajar. Jakarta: Departemen Pendidikan dan Kebudayaan Nasional

Pranata, K.B \& Sundaygara C \& Sinmas W.F (2019). Pengaruh PBL Berbasis Class Terhadap Prestasi Ditinjau Dari Motivasi Belajar Siswa. RAINSTEK: Jurnal Terapan Sains \& Teknologi 1 (3), 14-20, 2019

Trianto, I. B. (2014). Mendesain Model Pembelajaran Inovatif, Progresif, dan Konstektual: Konsep, Landasan, dan Implementasi pada Kurikulum 2013. Jakarta: Kencana.

Yunus, H. S. (2010). Metodologi Penelitian Wilayah Kontemporer. Yogyakarta: Pustaka Pelajar 
Zafira, L. (2012, Maret 14). Instrument Tes dan Nontes. Retrieved Februari 22, 2016, from http://liyanazafira.blogspot.co.id/2012/03/instrumen-tes-dan-nontes.html 